\title{
AN OESTROGEN-MEDIATED EFFECT OF PHOTOPERIOD ON THE REPRODUCTIVE BEHAVIOUR OF THE BUDGERIGAR
}

\author{
SUSAN GOSNEY AND R. A. HINDE \\ M.R.C. Unit on the Development and Integration of Behaviour, \\ University Sub-Department of Animal Behaviour, \\ Madingley, Cambridge CB3 $8 A A$
}

(Received 10th May 1975)

Budgerigar (Melopsittacus undulatus) reproductive development is affected by the photoperiod (Putman \& Hinde, 1973), and nest-hole entry by the female is accelerated by oestrogen (Hutchison, 1971). In the canary, long photoperiods affect nest-building behaviour, not only by the classical hypothalamus-pituitarygonad route, but also by influencing the effectiveness of exogenous oestrogen in ovariectomized birds (Steel \& Hinde, 1972). The present experiments were designed to assess whether the latter effect occurs also in the budgerigar.

Ovariectomy was performed by suction and cautery under sodium pentobarbitone and ether anaesthesia. After the operation the birds were transferred singly to the experimental cages and kept on an $11 \mathrm{hr}$ light:13 hr dark (11L: 13D) regimen for 2 days. The nest-box entrance was then opened and the birds tested for a further 7 days. Nest-box entry was assessed by the presence or absence of marks on a piece of smoked paper placed inside the box. Any birds entering during this period were rejected. The remaining birds were allocated randomly to the experimental groups. The birds were injected at approximately 10.00 hours thrice weekly beginning at Day 0 , with $0.1 \mathrm{mg} \beta$-oestradiol-3benzoate (Sigma Chemical Co.) in $0.1 \mathrm{ml}$ saline. The groups within each experiment were run concurrently. In Exps 1-4 the effectiveness of oestrogen in producing nest-box entry by ovariectomized females kept under short (8L: 16D) or long (14L:10D) photoperiods was tested. In Exps 5 and 6 a short photoperiod and a skeleton photoperiod was used $(6 \mathrm{~L}: 2 \mathrm{D}: 2 \mathrm{~L}: 14 \mathrm{D}$ and 6L:6D:2L:10D) to give a total of $8 \mathrm{hr}$ light. In Exps 1, 2 and 3, each cage was watched for $60 \mathrm{~min} /$ day between the 2nd and 4th $\mathrm{hr}$ after the initial 'lights on', and the period spent in the nest box was recorded. At the end of Exps 1 and 6 the birds were killed, and the birds with ovarian fragments greater than $0.1 \%$ of body weight were rejected from the analysis.

The birds in long photoperiods in Exps 1-4 showed a shorter median latency to enter the nest box, and a higher proportion of birds entering the nest box, than did those in the short photoperiods (Table 1). The latency difference was significant in Exps 1 and $4(P<0.05$, Mann-Whitney $U$ test, two-tailed).

In all experiments in which observations were made, birds in long photoperiods that entered the nest box spent a greater proportion of the available 
Table 1. The effect of different photoperiods on the nest-box behaviour of oestrogen-treated ovariectomized budgerigars

\begin{tabular}{|c|c|c|c|c|c|c|}
\hline \multirow{2}{*}{$\begin{array}{c}\text { Exp. no. } \\
\text { (month) }\end{array}$} & \multirow{2}{*}{ Photoperiod } & \multirow{2}{*}{$\begin{array}{l}\text { No. of } \\
\text { birds }\end{array}$} & \multirow{2}{*}{$\begin{array}{l}\text { Length of } \\
\text { exp. (days) }\end{array}$} & \multicolumn{2}{|c|}{$\begin{array}{l}\text { Latency to enter } \\
\text { nest box (days) }\end{array}$} & \multirow{2}{*}{$\begin{array}{l}\text { No. of birds } \\
\text { entering } \\
\text { nest box }\end{array}$} \\
\hline & & & & Median & Range & \\
\hline 1 (February) & $\begin{array}{r}\text { 8L: } 16 \mathrm{D} \\
14 \mathrm{~L}: 10 \mathrm{D}\end{array}$ & $\begin{array}{l}8 \\
7\end{array}$ & 13 & $\begin{array}{l}3 \\
1\end{array}$ & $\begin{array}{l}2-5 \\
1-3\end{array}$ & $\begin{array}{l}5 \\
7\end{array}$ \\
\hline 2 & $\begin{array}{r}8 \mathrm{~L}: 16 \mathrm{D} \\
14 \mathrm{~L}: 10 \mathrm{D}\end{array}$ & $\begin{array}{l}8 \\
9\end{array}$ & 19 & $\begin{array}{l}19 \\
12\end{array}$ & $\begin{array}{l}2-19 \\
5-15\end{array}$ & $\begin{array}{l}5 \\
7\end{array}$ \\
\hline $\begin{array}{l}3 \\
\text { (June) }\end{array}$ & $\begin{array}{r}8 \mathrm{~L}: 16 \mathrm{D} \\
14 \mathrm{~L}: 10 \mathrm{D}\end{array}$ & $\begin{array}{r}9 \\
10\end{array}$ & 20 & $\begin{array}{l}9 \cdot 8 \\
5\end{array}$ & $\begin{array}{l}2-12 \\
1-20\end{array}$ & $\begin{array}{l}6 \\
8\end{array}$ \\
\hline $\begin{array}{l}4 \\
\text { (July) }\end{array}$ & $\begin{array}{l}\text { 8L: 16D } \\
14 \mathrm{~L}: 10 \mathrm{D}\end{array}$ & $\begin{array}{l}5 \\
5\end{array}$ & 13 & $\begin{array}{r}10 \\
1\end{array}$ & $\begin{array}{l}5-12 \\
1-8\end{array}$ & $\begin{array}{l}4 \\
5\end{array}$ \\
\hline $\begin{array}{l}5 \\
\text { (October) }\end{array}$ & $\begin{array}{c}8 \mathrm{~L}: 16 \mathrm{D} \\
6 \mathrm{~L}: 2 \mathrm{D}: 2 \mathrm{~L}: 14 \mathrm{D} \\
6 \mathrm{~L}: 6 \mathrm{D}: 2 \mathrm{~L}: 10 \mathrm{D}\end{array}$ & $\begin{array}{l}6 \\
6 \\
6\end{array}$ & 16 & $\begin{array}{l}5 \cdot 5 \\
4 \cdot 5 \\
5 \cdot 5\end{array}$ & $\begin{array}{l}2-7 \\
1-7 \\
2-11\end{array}$ & $\begin{array}{l}4 \\
4 \\
5\end{array}$ \\
\hline $\begin{array}{l}6 \\
\text { (November) }\end{array}$ & $\begin{array}{c}\text { 8L:16D } \\
6 \mathrm{~L}: 2 \mathrm{D}: 2 \mathrm{~L}: 14 \mathrm{D} \\
6 \mathrm{~L}: 6 \mathrm{D}: 2 \mathrm{~L}: 10 \mathrm{D}\end{array}$ & $\begin{array}{r}10 \\
9 \\
8\end{array}$ & 13 & $\begin{array}{l}6 \cdot 8 \\
7 \\
2 \cdot 5\end{array}$ & $\begin{array}{l}2-9 \\
1-7 \\
1-8\end{array}$ & $\begin{array}{l}6 \\
5 \\
8\end{array}$ \\
\hline
\end{tabular}

light period in the box than those in short photoperiods that entered. In Exp. 1 the median proportion of time spent in the nest box by those birds that entered was greater for the long-photoperiod group on 9 out of the 10 days on which any bird entered during the experiment $(P<0.03$, Binomial test, two-tailed). Birds in the long-photoperiod group also spent a significantly greater amount of time in the nest box on 2 of these days $(P<0.05$, Mann-Whitney $U$ test, twotailed). In Exps 2 and 3 the time spent in the nest box was greater on 5 out of 5 days and 7 out of 9 days, respectively, but the differences were not significant.

In each of Exps 5 and 6 a higher proportion of birds kept in the $6 \mathrm{~L}: 6 \mathrm{D}: 2 \mathrm{~L}$ : $10 \mathrm{D}$ regimen entered the nest box than did birds kept in either of the others. The median latencies were shorter in the skeleton groups than those receiving continuous light. None of these differences was significant.

These data indicate that oestrogen-treated ovariectomized budgerigars kept in long photoperiods entered the nest box sooner, spent longer in the nest box and a higher proportion of the light period in the nest box, than birds kept in short photoperiods. The possibility that the time available for entering was an important issue per se is unlikely because of the results obtained in the skeletonday experiments, though these were not significant. Regeneration of ovarian fragments is probably unimportant because only two birds were rejected at autopsy in Exps 1 and 6:27 of the 42 remaining birds had no ovarian fragments, and there was no significant difference between the oviduct weights of those with ovarian fragments left and those with none.

In the budgerigar, therefore, as in the canary, the photoperiod can affect reproductive behaviour when the gonad is absent.

\section{REFERENCES}

Hurchison, R.E. (1971) The integration of reproductive behaviour in female budgerigars. Ph.D. thesis, University of Cambridge.

Putman, R.J. \& Hinde, R.A. (1973) Effects of light regime and breeding experience on budgerigar reproduction. 7. Zool., Lond. 170, 475-484.

Steel, E. \& Hinde, R.A. (1972) Influence of photoperiod on oestrogenic induction of nest building in canaries. F. Endocr. 55, 265-278. 